\title{
The Role of Parents in Cultivating Characters through Pencak Silat Sport at The Pandemic COVID-19 in Sub-District Sukasada Buleleng, Bali
}

\author{
Gusti Ngurah Arya Yudaparmita ${ }^{1}$, I Putu Yoga Purandina ${ }^{2}$ \\ \{aryayuda562@gmail.com ${ }^{1}$, yogapurandina@stahnmpukuturan.ac.id ${ }^{2}$ \} \\ Sekolah Tinggi Agama Hindu Negeri Mpu Kuturan Singaraja \\ Singaraja, Indonesia ${ }^{1,2}$
}

\begin{abstract}
Abstrak. During the COVID-19 Pandemic, children's fitness must be maintained. Children's character education must be instilled. Likewise, children 5 - 11 years of age in the Sukasada district of Buleleng, Bali received extracurricular sports of Pencak Silat at a distance during the COVID-19 Pandemic. This study aims to know the sports extracurricular program of Pencak Silat during the COVID-19 pandemic. Determining the role of parents in cultivating character through the sport of Pencak Silat during the COVID-19 pandemic in the sub-district of Sukasada, Buleleng, Bali. As well as character values instilled through the sport of Pencak Silat during the COVID-19 pandemic in the Sukasada sub-district, Buleleng. This research is a qualitative study using a Google form survey instrument and random interviews with 64 children and parents in the Sukasada sub-district. The results of this study indicate that the Pencak Silat sports extracurricular program can run well through online learning with the guidance of parents at home by using Zoom, a YouTube application. Parents have a neutral role by doing joint exercises, assisting children in doing exercises, preparing a comfortable place for children to practice, establishing intense communication with children and teachers, being positive character role models, meeting children's needs in training, motivating children, provide education, instill character values, carry out variations and innovate activities. There are 18 character values instilled in the extracurricular activities of Pencak Silat during the COVID-19 pandemic, namely religious, honest, tolerance, discipline, hard work, creative, independent, democratic, curiosity, national spirit, love of the motherland, achievement appreciation, friendly/communicative, peace, love to read, environmental care, social care, and responsible.
\end{abstract}

Keywords: Role of Parents; Cultivating Character; Pencak Silat; COVID-19 Pandemic

\section{Introduction}


This COVID-19 pandemic is very dangerous, even more, widespread and there are no signs of an end to this pandemic [1]. Another term is SARS-CoV-2 (Severe Acute Respiratory Syndrome Corona Virus 2) which can attack the human respiratory system [2][3]. This virus can grow in the human body as a host cell. Then it can be transmitted through droplets or liquids that come out through the respiratory tract, droplets produced when an infected person coughs or sneezes [4]. This fluid will later transmit to other individuals by accidentally touching, then being inhaled and entering the respiratory tract [5]. The earliest clinical sign of disease related to SARS-CoV-2 COVID-19 that allows case detection is pneumonia. In symptomatic patients, clinical manifestations of the disease usually begin in less than a week, consisting of fever, cough, nasal congestion, fatigue, and other signs of upper respiratory tract infection [6][7][8].

This virus is so dangerous, that preventive measures are needed to be able to break the chain of the spread of COVID-19 [9]. The most important strategy for the community is to wash their hands frequently and use portable hand sanitizers and avoid contact with their faces and mouths after interacting with potentially contaminated environments [10]. To reduce the risk of transmission in the community, individuals should be advised to wash their hands diligently, practice respiratory hygiene (i.e., cover their coughs), and avoid crowds and close contact with sick individuals, where possible [4][11]. In addition, the body's immune system must always be maintained and continuously improved. Viruses that weaken the body's immune system will slowly defeat the immune system in the human body. So various ways to keep the body's immune good must be done [12].

Maintaining the body's immune system to stay fit and well requires maintaining a healthy diet and doing various physical activities [13]. A diet that contains more vitamins and fiber is good for the body. In the form of foods that contain sufficient nutrients and supplements that are needed in the body. Like vegetables and fruits that contain so much fiber and vitamins [14][12] Likewise, adequate fluid intake must be maintained, adequate sleep, and regular physical activity such as doing light exercise every day [15]. Body fitness will always be maintained, so it can boost the immune system, and ward off various diseases that attack the body [16].

Physical activity is a scourge and difficult for everyone to do in this digital era. Jobs that require physical activity have begun to decrease, as well as human activities that are getting easier [17]. We can see that in various situations and conditions in this era, physical activity has begun to be abandoned. Physical activity is not necessarily a sport. Indeed, exercise includes physical activity as well. Physical activity is a bodily movement that can release energy and burn energy. Physical activity that is good, correct, measurable, and regular will get maximum results [18]. Physical activity and exercise not only maintain physical health, but psychologically it also has a positive impact on everyone's psyche [19]. It can even help our body to respond to the negative consequences of some diseases such as diabetes, hypertension, cardiovascular disease, and respiratory disease [20][21].

In physical activity, exercises that move several organs of the body must be done. Exercise is shown to keep other physical functions (respiratory, circulatory, muscular, nervous, and skeletal systems) intact and to support other systems (endocrine, digestive, immune, or renal systems) that are important in fighting known or unknown threats to the body [22][23]. All of these vital organs must be kept stable in their function. Trained regularly so that the working systems that involve organ and endocrine functions run smoothly. Just like a machine, the body also has a system that must be maintained, and the way to maintain it is of course with various physical activity exercises and a balanced diet. 
During this COVID-19 pandemic, physical activity and exercise are highly recommended. Regular physical activity, while taking other precautions, is also considered effective in dealing with the health outcomes of the COVID-19 Pandemic [24][25]. Researchers from the University of Virginia Health System [26] showed that regular exercise can significantly reduce the risk of acute respiratory distress syndrome, which is one of the leading causes of death in COVID-19 patients. During the COVID-19 Pandemic, there were many restrictions, including distance, crowd, and regional restrictions. So many government and private agencies do Work From Home (WFH). There is more time at home so that physical activity is more likely to be done during WFH.

In addition, exercise can play an important role in promoting positive mental health and well-being [27]. Exercise can not only improve physical fitness but can also provide mental health. Psychological health must also be maintained during this COVID-19 Pandemic [28]. It is undeniable, during the COVID-19 Pandemic, the biggest problem besides physical health is of course psychological health which can later affect overall health. So that it becomes easily infiltrated by various kinds of viruses and bacteria that cause disease, such as COVID-19.

During this COVID-19 pandemic, various problems will certainly arise. Problems caused by various conditions, be it health, economy, education, industry, etc [29]. During this COVID-19 pandemic, WHO also conducted a campaign to continue to do physical activity. Physical activity can overcome or prevent the body from being infected by non-communicable diseases (NCDs) [30]. Health at home is the emphasis of WHO, which to stay at home indefinitely will be deep boredom for some people. The difficulty of managing time in dividing time for activities at home is one of the problems. Staying at home will also make some people lazy and forget various activities that should be done. So that the organs of the body do not experience significant movement and cause the various operating systems in the human body to fail [31][32].

The same is true in the world of education. The world of education, especially in Indonesia during the COVID-19 pandemic, applies distance learning and blended learning [33]. So that children access their learning from home, and teachers provide learning from home or school. The point is that learning is carried out remotely using online learning or even mixed learning that still prioritizes health protocols. This is what creates a significant problem in the world of education. Teachers and students have difficulty in the learning process. Teachers have difficulty in designing and providing learning to students, as well as students experiencing difficulties in accessing their learning [34].

Especially in the primary education unit, it is very difficult for children to get the social stimulus. Children in basic education units in addition to getting cognitive learning should get social stimuli that can build social-emotional intelligence [35]. Likewise, his physical development must still be trained to grow into a strong and tough child when he grows up. Even though during the COVID-19 Pandemic they mostly do activities at home, it should still be determined and ensured regarding various social stimuli and children's physical activities [36]. Teachers and parents must be able to synergize to continue to provide good activities for children's social, physical, and health development.

These children's emotional social activities must be maintained so that they can also foster strong character education for children. Cognitive learning can indeed be easily done online, but what about learning that demands social development such as character education which demands the development of children's behavior in a better direction according to their growth and development [37]. So that during the COVID-19 pandemic, character education and sports education must continue to be held [38]. The collaboration of teachers and parents is the key to distance learning. Parents replace the role of teachers, fill in the empty spaces that should be 
occupied by teachers to monitor children's development, now parents have additional tasks [39].

As happened in elementary school in Sukasada sub-district, Buleleng Bali. Sports education is still provided during the pandemic and even continues to provide Pencak silat which is provided and monitored remotely by the teacher. The teacher asks parents for help in providing Pencak silat training activities together. Children and parents together do this Pencak silat exercise. Of course, maintaining fitness and social activities between children and parents are the focus of this activity, but besides that, the sport of Pencak silat is indeed good for the social-emotional development of children, especially in the growth of character education for children [40][41].

So, in this study, we investigated how this Pencak silat extracurricular activity was carried out in elementary schools, in Sukasada District, Buleleng Regency. The role of parents in the involvement of parents in extracurricular Pencak silat activities in elementary schools, in Sukasada District, Buleleng Regency. Kind of character values can be grown in extracurricular Pencak silat activities in elementary schools, in Sukasada District, Buleleng Regency, Bali.

\section{Method}

The design of this study is qualitative research that emphasizes the depth of investigation of phenomena that occur in the social environment. The qualitative research here focuses on investigating the quality of relationships, activities, sites, and materials [42]. In qualitative research, the researcher is the key instrument that plays the main role as a data processor who has intuition in solving problems that occur in the field. Qualitative research studies include setting, place conditions, and situations as direct data. Research like this is very suitable for investigating people, events, groups of people, and institutions [43].

Noting this, in this study the researchers analyzed The Role of Parents in Cultivating Characters through Pencak Silat Sport at The Pandemic Covid-19 in Sub-District Sukasada Buleleng, Bali. Including how the process of extracurricular activities of Pencak silat and what character values are instilled in this activity by the parents of students. The data used in this study are the results of interviews with students, parents, and teachers. There is also an observation sheet, as well as a questionnaire distributed via Google Form. The use of applications in the form of Google Forms, Zoom, etc. is very helpful in the data search process. Observation and interview data are needed to find data on the extra-curricular activity process and how the role of parents in extracurricular activities of Pencak silat in Elementary School, Sukasada District, Buleleng, Bali. Meanwhile, questionnaire data is needed to find character values that can be grown in this activity [44].

As explained earlier, the researcher is a key instrument in qualitative research, which has an intuition about the existing phenomena or problems. Also assisted with other instruments in the form of observation sheets, interview guides, and questionnaires which were transformed into online form via Google Form. All of these instruments have gone through a validation process carried out by expert judges. These expert judges have professionalism in the field of online learning, especially regarding the sport of Pencak silat and also in the field of character education. All instruments are very appropriate to be used in this study which emphasizes qualitative research. Indeed, to find objective data, you must use instruments in conducting observations and obtaining data [45]. 
In addition, to obtain correct and precise data, the reliability and validity of the data must be considered. Therefore, the data obtained must go through a process of cross-checking (cross-checked data) and repeated data collection. This process is a triangulation process [46][47][48]. This triangulation also get accurate data, diverse data, or various data acquisitions that can be combined [49]. Likewise, the trustworthiness of data is also carried out in this study which includes four aspects, namely the data itself, data transcription, data collection techniques, and findings.

The data analysis approach used is the Miles-Huberman approach. This approach consists of three concepts, namely data reduction which is carried out directly at the time of data collection. The second is the presentation of the data (data display), and the third is the verification of the conclusion or drawing the conclusion [50][51]. This analytical approach is used directly and continuously as a part of the process of investigating the phenomena in this research. In analyzing the data obtained, it is done interactively and simultaneously, until finally the answer or solution to the research question is answered to the saturation of the data. In qualitative research, there is no limit to the data found, but in qualitative research, the end of a search is when the data obtained is data that has reached data saturation. Saturated means that the data obtained is always the same, so there is no need for repetition. Of course, the data in question is data related to The Role of Parents in Cultivating Characters through Pencak Silat Sport at The Pandemic Covid-19 in Sub-District Sukasada Buleleng, Bali which was discussed taking into account various aspects.

\section{Result and Discussion}

This section will be divided into three parts, according to the research question mentioned in the introduction. The three parts are how the extracurricular activities of Pencak silat in elementary schools, in Sukasada District. Second, the role of parents in extracurricular activities of Pencak silat in elementary schools, in Sukasada District. Third, character values can be grown in extracurricular activities of Pencak silat in elementary schools, in Sukasada District.

\subsection{Pencak Silat Sports Extracurricular Activities at Elementary Schools, Sukasada District}

Pencak Silat sports extracurricular activities in Elementary Schools, Sukasada District, Buleleng Regency are indeed very important activities in supporting education, both academic and non-academics, especially at the Elementary School level in Sukasada District. Extracurricular activities are character development activities to expand and discover the potential, talents, interests, abilities, personality, cooperation, and independence of students. This activity is carried out outside of study hours which is carried out optimally through the supervision of the education unit [52]. So that extracurricular activities in elementary schools in Sukasada District are a priority that can support student character and achievement.

However, during the COVID-19 pandemic, extracurricular activities have become difficult to organize. Extracurricular activities before the COVID-19 pandemic were carried out offline and at schools [34]. Children can directly develop their potential and build their character by receiving coaching, training, and supervision from teachers or coaches. Certainly, children find it easier to follow the exercises directly and get moral touches by direct action, imitating positive behaviors that occur during extracurricular activities. Children can also interact with 
other children which will later form their social relationships. And the most important thing is to maintain the fitness and health of children during this COVID-19 Pandemic by doing physical activity and sports together regularly, to increase the body's immune strength.

Through the process of observing and interviewing teachers in elementary schools, in Sukasada District, Buleleng Regency, it was discovered that there were extracurricular activities that could not work at all because distance learning was very difficult. However, some extracurricular activities can be done remotely, which can be done at the students' own homes. One of them, and the object of this research is the extracurricular activities of Pencak silat. The teachers and trainers confirmed that the sport of Pencak silat could still be held during this distance learning. The method used is by conducting online joint activities guided by teachers or trainers.

This online activity is carried out through the Zoom application, supported by tutorial videos via YouTube, as well as digital guidebooks. In addition, teachers or trainers open WhatsApp Groups for communication needs and maintain closeness between teachers and students. This WAG is also useful for facilitating communication between teachers and parents because, in the learning process or remote activities, children must still be monitored, supervised, and guided properly [53][54]. So that the role of parents becomes very important in organizing this extracurricular activity of Pencak silat.

Indeed, on several occasions, offline activities were held but with strict health protocols. In offline activities, children will be allowed to come to school but by limiting the amount and time of practice. The exercise is only a confirmation and evaluation of the activities carried out remotely. So it can be said that this offline activity is only carried out to confirm and evaluate the development and monitor the potential of children to step up to the level of achievement. Children are not forced to come to school, but rather provide an opportunity if there are children who want to come to school to further improve their children's abilities.

The steps in the process of extracurricular activities for Pencak silat at elementary schools in Sukasada District include a complete weekly activity plan containing tutorials on actionable steps that can be followed by children and accompanied by parents at home. The second step is to communicate with parents if at a certain time there will be activities and explain the kinds of movements that will be carried out in a meeting. How to do the moves, etc. The third step is the main activity, where children and parents together follow the movements determined by the teacher or trainer through video tutorials or live conferences via Zoom. Fourth is offline activities, where children are allowed to come to school with strict health protocols. But still given the right not to come.

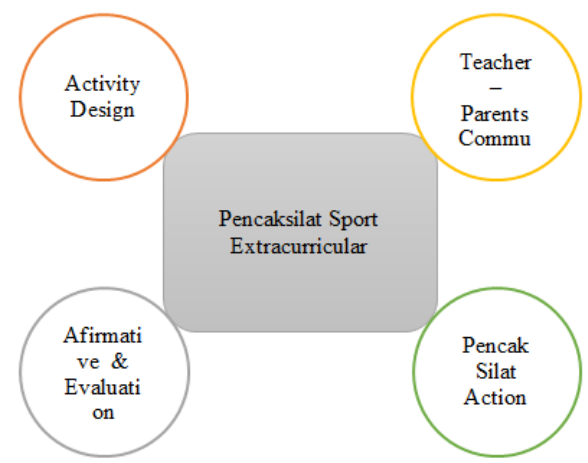

Fig. 1. Steps for Pencak Silat Extracurricular Activities in Elementary Schools, Sukasada District. 
This series of activity steps are carried out continuously and is still evaluated by the head of the education unit (the headmasters) and gets input from parents and all stakeholders. Based on data from interviews with teachers, coaches, and parents, they showed a fairly high enthusiasm because sports activities in general and extracurricular activities for Pencak silat are indeed very good and important to do. During the COVID-19 pandemic, they believe that children's health and fitness must be maintained while learning from home [27]. One way to keep children fit is by doing physical activities and sports [55]. So this extracurricular activity is a way to improve children's fitness and health. What's more, it can be a joint activity with their respective families at home, so that the whole family maintains their fitness [56].

In addition, this extracurricular activity is a place to grow children's character values [57]. Sports, especially Pencak silat, are very good for growing children's character [41]. Indeed, children's character can be developed through extracurricular activities, through these activities children learn how to interact, carry out their obligations, and accept new challenges to increase their confidence [38]. So that positive characters will appear who can later become role models for children. In sports extracurricular activities in elementary schools in Sukasada District, the interaction that exists is the interaction between strong family members.

\subsection{The Role of Parents in Pencak Silat Sports Extracurricular Activities at Elementary Schools, Sukasada District during the COVID-19 Pandemic}

By conducting in-depth interviews with teachers/coaches, parents, and also students, the extracurricular activities of Pencak silat during the COVID-19 pandemic need the role of parents. Parents have a very vital role where in addition to being a companion, caregiver for children while at home, parents must also be able to become a shadow teacher/trainer figure, replacing the actual teacher/coach figure. This can be an obstacle if parents are not able to provide roles to facilitate the process of extracurricular activities of Pencak silat in elementary schools, in Sukasada District, Buleleng Regency, Bali.

Tabel 1. The Role of Parents in Pencak Silat Extracurricular Activities at Elementary Schools,

\begin{tabular}{ll}
\multicolumn{1}{c}{ Sukasada District During the COVID-19 Pandemic. } \\
\hline Role of Parents & \multicolumn{1}{c}{ Goals } \\
Places Vendor & $\begin{array}{l}\text { To maintain relationships and explain information from } \\
\text { teacher to children } \\
\text { To provide a comfortable place atmosphere when practicing } \\
\text { Pencak silat at home } \\
\text { To fulfill adequate facilities to support Pencak silat training } \\
\text { activities at home } \\
\text { To accompany and fight training in Pencak silat }\end{array}$ \\
Sparring Partner & $\begin{array}{l}\text { To ensure the trainer's instructions can be understood by the } \\
\text { child } \\
\text { To give and keep children's spirit in Pencak Silat practices }\end{array}$ \\
Motivator & $\begin{array}{l}\text { To monitor and maintain children's fitness and health } \\
\text { Fitness Assistant }\end{array}$ \\
Character Model/Builder & $\begin{array}{l}\text { To provide examples of positive behavior attitudes, cultivate } \\
\text { character values. }\end{array}$ \\
\hline
\end{tabular}

The table above is the result of data from a questionnaire that was made in the form of a Google Form, then distributed randomly through the Google Form application to parents 
whose children participated in extracurricular Pencak silat activities during the COVID-19 Pandemic at an elementary school in Sukasada District, Buleleng Regency. The data is sorted according to the data with the most choice of answers to questions regarding the role of parents during extracurricular activities of Pencak silat which are carried out at home. From about 50 parents who filled in, it was found that there were eight very vital roles of parents in this extracurricular activity. As Communicator \& Mediator, Place Vendor, Tools Supplier, Sparring Partner, Coach Assistant, Motivator, Fitness Assistant, Character Model/Builder.

Additionally, through direct observations, as a communicator \& mediator, parents must be a mediator in maintaining communication between coaches and children. Activities carried out remotely are certainly one of the inhibiting factors. Children will find it difficult to understand what is instructed by the coach. Likewise, the coach will find it difficult to monitor or understand the development or problems faced by children at home. This is where parents maintain the continuity of smooth communication between coaches and children. Then as a place vendor, parents are obliged to prepare a comfortable place to maintain the comfort of their children to do the exercises.

As a tools supplier, it is obligatory to facilitate the adequacy of this Pencak silat training facility at home. Simple facilities that can be fulfilled to support the training process such as computers/gadgets, clothes, sticks, etc. As a separation partner, parents must be able to accompany their children to become friends for Pencak silat training, together with do the basic movements of Pencak silat, carry out committee movements, etc. Then, as coach assistants, parents must be able to provide examples, provide explanations about the coach's instructions so that they are more easily understood by children. As a motivator, parents must be able to encourage, keeping the child's mood rather not lazy and bored in doing this activity. As fitness assistants, parents must continue to monitor the fitness and health, and nutritional intake of their children during this COVID-19 pandemic. Finally, as character models, parents must be able to provide examples of good and positive behavior following positive character values that apply in society.

\subsection{Character Values Grown in Pencak Silat Extracurricular Activities at Elementary Schools, Sukasada District during the COVID-19 Pandemic}

The results of observations on extracurricular activities of Pencak silat which are carried out remotely and accessed from home, parents can also establish a better relationship with their children. Parents spend more time with their children and engage in more intense activities and communication. This certainly establishes and fosters a loving closeness between parents and children. Children become more enthusiastic and will always have a sense of pride in their parents. This is where parents become role models for children. Children will follow and imitate the behavior of their parents while at home. So that activities carried out together with parents create a positive character that can affect the child's psychological, mental development, and social behavior.

In general, the characters that can be developed in this activity are being able to cultivate courage, develop self-confidence, cultivate discipline, foster sportsmanship, cultivate socialization skills, and love the homeland and Indonesian culture. Associated with the 18 character values proclaimed by the Indonesian Ministry of Education and Culture, this study found 18 character values that are trying to be grown through extracurricular activities of Pencak silat in elementary schools, in Sukasada District, during this COVID-19 pandemic. The following are the character values that can be grown displayed in the table. 
Tabel 2. Character Values Grown in Pencak Silat Extracurricular Activities during the COVID-19 Pandemic.

\begin{tabular}{|c|c|}
\hline Character Values & Activities \\
\hline Religious & Pray before and after activities, respect parents and coaches \\
\hline Honest & Be honest with words and actions in doing exercises \\
\hline Tolerance & $\begin{array}{l}\text { Respect and appreciate differences even though there are } \\
\text { children and coaches of different religions and ethnicities }\end{array}$ \\
\hline Discipline & $\begin{array}{l}\text { Orderly, obedient, punctual, and willing to follow every } \\
\text { movement in every single practice }\end{array}$ \\
\hline Hard Work & $\begin{array}{l}\text { Willing and able to follow the movements and all activities } \\
\text { in the melting martial arts training }\end{array}$ \\
\hline Creative & $\begin{array}{l}\text { Willing and able to follow, as well as providing movement } \\
\text { initiative in a combat exercise }\end{array}$ \\
\hline Independent & $\begin{array}{l}\text { Willing and able to perform Pencak silat movements } \\
\text { independently without the help of parents }\end{array}$ \\
\hline Democratic & $\begin{array}{l}\text { Willing and learn not to impose will on parents and others, } \\
\text { not spoiled }\end{array}$ \\
\hline Curiosity & $\begin{array}{l}\text { Willing to find out every step or how to move to this } \\
\text { exercise }\end{array}$ \\
\hline National Spirit & $\begin{array}{l}\text { Has the ambition to keep the country by training to be strong } \\
\text { with Pencak silat training }\end{array}$ \\
\hline Love the Motherland & $\begin{array}{l}\text { Willing to preserve culture and uphold the character of the } \\
\text { nation }\end{array}$ \\
\hline Achievement Appreciation & $\begin{array}{l}\text { Willing to appreciate and give and receive praise and } \\
\text { enthusiasm to maintain cohesiveness in practice }\end{array}$ \\
\hline Friendly/Communicatif & $\begin{array}{l}\text { Communicate and build good relationships, don't say rude } \\
\text { things to parents, coaches, and friends }\end{array}$ \\
\hline Peace & $\begin{array}{l}\text { Maintain positivity and not arrogant and conceited when } \\
\text { training, apologize if it hurts the opponent }\end{array}$ \\
\hline Love to Read & $\begin{array}{l}\text { Willing and able to read and seek information provided by } \\
\text { coaches and parents }\end{array}$ \\
\hline Environmental Care & $\begin{array}{l}\text { Cleaning equipment and training areas before and after } \\
\text { training, including maintaining personal hygiene and health }\end{array}$ \\
\hline Social Care & $\begin{array}{l}\text { Dare to tell and show information and kinds of movements } \\
\text { in an informative way }\end{array}$ \\
\hline Responsible & $\begin{array}{l}\text { Take responsibility for actions, admit mistakes, and keep } \\
\text { tools and places in good condition }\end{array}$ \\
\hline
\end{tabular}

These 18 characters could not be found in full during the activity, but during observations, interviews, and data on the questionnaire, it was found that these 18 characters appeared in this activity. This will be a positive character education that can be done as long as the child is doing Learning from Home during this COVID-19 Pandemic. There are so many benefits that can be grown in children through extracurricular activities of Pencak silat in elementary schools, Sukasada District, Buleleng Regency. In addition, character education in the family environment is very appropriate to be developed during this COVID-19 pandemic. A good momentum can be done by parents [38]. However, the family is the first environment known to the child so that it has a strong inner bond in it [56]. So that the process of growing character values will be better and easier for children to assimilate.

\section{Conclusion}


The COVID-19 pandemic has become an obstacle for children to learn and carry out social activities such as extracurricular activities at school. However, the elementary school education unit in Sukasada District, Buleleng tries to continue to organize extracurricular activities for Pencak silat by conducting long-distance activities online and offline. This activity aims to maintain the fitness and health of children during the COVID-19 Pandemic. Likewise, to continue to monitor the potential, achievements, interests, and talents of children so that they are channeled. In this activity, activity plans were prepared such as activity design, teacher-parents communication, Pencak silat action, affirmative \& evaluation. The role of parents becomes very vital because the role of coaches seems to be imposed on parents such as Communicator \& Mediator, Place Vendor, Tools Supplier, Sparring Partner, Coach Assistant, Motivator, Fitness Assistant, Character Model/Builder. Then this activity is also very good in growing children's character values while at home. The character values that grow are religious, honest, tolerance, discipline, hard work, creative, independent, democratic, curiosity, national spirit, love the motherland, achievement appreciation, friendly/communicative, peace, love to read, environmental care, social care, and responsible. This research is expected to be able to provide a new picture of sports activities, especially Pencak silat during the COVID-19 pandemic, and can be done at home with family.

\section{References}

[1] J. J. Van Bavel et al., "Using social and behavioural science to support COVID-19 pandemic response," Nat. Hum. Behav., vol. 4, no. 5, pp. 460-471, 2020, doi: 10.1038/s41562-020-0884-z.

[2] S. K. Kar, S. M. Yasir Arafat, R. Kabir, P. Sharma, and S. K. Saxena, "Coping with Mental Health Challenges During COVID-19 BT - Coronavirus Disease 2019 (COVID-19): Epidemiology, Pathogenesis, Diagnosis, and Therapeutics," S. K. Saxena, Ed. Singapore: Springer Singapore, 2020, pp. 199-213.

[3] S. K. Saxena, Coronavirus Diseas 2019 (COVID-19): Epidemoogy, Pathogenis, Diagnosis, and Therapeutics. Singapore, 2020.

[4] R. Güner, İ. Hasanoğlu, and F. Aktaş, "Covid-19: Prevention and control measures in community," Turkish J. Med. Sci., vol. 50, no. SI-1, pp. 571-577, 2020, doi: 10.3906/sag-2004-146.

[5] J. F. W. Chan, S. K. P. Lau, K. K. W. To, V. C. C. Cheng, P. C. Y. Woo, and K. Y. Yue, "Middle East Respiratory syndrome coronavirus: Another zoonotic betacoronavirus causing SARS-like disease," Clin. Microbiol. Rev., vol. 28, no. 2, pp. 465-522, 2015, doi: 10.1128/CMR.00102-14.

[6] Y. Bai et al., "Presumed Asymptomatic Carrier Transmission of COVID-19," JAMA, vol. 323, no. 14, pp. 1406-1407, Apr. 2020, doi: 10.1001/jama.2020.2565.

[7] Q. Li et al., "Early Transmission Dynamics in Wuhan, China, of Novel CoronavirusInfected Pneumonia,” N. Engl. J. Med., vol. 382, no. 13, pp. 1199-1207, 2020, doi: 10.1056/nejmoa2001316.

[8] W. Guan et al., "Clinical Characteristics of Coronavirus Disease 2019 in China," N. Engl. J. Med., vol. 382, no. 18, pp. 1708-1720, Feb. 2020, doi: 10.1056/NEJMoa2002032.

[9] C. Sica et al., "Health Anxiety Predicts the Perceived Dangerousness of COVID-19 over and above Intrusive Illness-Related Thoughts, Contamination Symptoms, and State and Trait Negative Affect," International Journal of Environmental Research and 
Public Health, vol. 18, no. 4. 2021, doi: 10.3390/ijerph18041933.

[10] T. P. Velavan and C. G. Meyer, "The COVID-19 epidemic," Trop. Med. Int. Health, vol. 25, no. 3, pp. 278-280, Mar. 2020, doi: 10.1111/tmi.13383.

[11] V. M. Arora, M. Chivu, A. Schram, and D. Meltzer, "Implementing physical distancing in the hospital: A key strategy to prevent nosocomial transmission of COVID-19," $J$. Hosp. Med., vol. 15, no. 5, pp. 290-291, 2020, doi: 10.12788/jhm.3434.

[12] M. Iddir et al., "Strengthening the Immune System and Reducing Inflammation and Oxidative Stress through Diet and Nutrition: Considerations during the COVID-19 Crisis," Nutrients , vol. 12, no. 6. 2020, doi: 10.3390/nu12061562.

[13] S. C. Weller and B. N. Vickers, "Identifying sustainable lifestyle strategies for maintaining good glycemic control: a validation of qualitative findings," BMJ Open Diabetes Res. \&amp;amp; Care, vol. 9, no. 1, p. e002103, Apr. 2021, doi: 10.1136/bmjdrc-2020-002103.

[14] L. Marty, B. de Lauzon-Guillain, M. Labesse, and S. Nicklaus, "Food choice motives and the nutritional quality of diet during the COVID-19 lockdown in France," Appetite, vol. 157, p. 105005, 2021, doi: https://doi.org/10.1016/j.appet.2020.105005.

[15] N. Rezaei and M. A. Grandner, "Changes in sleep duration, timing, and variability during the COVID-19 pandemic: Large-scale Fitbit data from 6 major US cities," Sleep Heal., vol. 7, no. 3, pp. 303-313, 2021, doi: https://doi.org/10.1016/j.sleh.2021.02.008.

[16] A. Bellicha et al., "Effect of exercise training on weight loss, body composition changes, and weight maintenance in adults with overweight or obesity: An overview of 12 systematic reviews and 149 studies," Obes. Rev., vol. n/a, no. n/a, p. e13256, May 2021, doi: https://doi.org/10.1111/obr.13256.

[17] S. I. Zizikova, I. V. Nikolaeva, and O. B. Paramonova, "Digital Autism as a Factor of Reduced Physical Activity of the Population," in Current Achievements, Challenges and Digital Chances of Knowledge Based Economy. Lecture Notes in Networks and Systems, 133rd ed., S. Ashmarina and V. Mantulenko, Eds. Springer, Cham, 2021.

[18] B. Cheval and M. P. Boisgontier, "The Theory of Effort Minimization in Physical Activity," Exerc. Sport Sci. Rev., vol. 49, no. 3, pp. 168-178, Jul. 2021, doi: 10.1249/JES.0000000000000252.

[19] B. C. Foley, K. B. Owen, A. E. Bauman, W. Bellew, and L. J. Reece, "Effects of the Active Kids voucher program on children and adolescents' physical activity: a natural experiment evaluating a state-wide intervention," BMC Public Health, vol. 21, no. 1, p. 22, 2021, doi: 10.1186/s12889-020-10060-5.

[20] L. M. Azevêdo, L. S. Santos, E. Pardono, J. A. Almeida, and A. S. Menezes, "Physical Activity Level, Anthropometric and Cardiovascular Profile Among Students in Sergipe State Attending Public Schools," Int. J. Cardiovasc. Sci., vol. 34, no. 3, pp. 255-261, 2020, doi: 10.36660/ijcs.20200050.

[21] K. K. Sahu, A. D. Siddiqui, N. Rezaei, and J. Cerny, "Challenges for management of immune thrombocytopenia during COVID-19 pandemic," J. Med. Virol., vol. 92, no. 11, pp. 2277-2282, Nov. 2020, doi: https://doi.org/10.1002/jmv.26251.

[22] D. Jiménez-Pavón, A. Carbonell-Baeza, and C. J. Lavie, "Physical exercise as therapy to fight against the mental and physical consequences of COVID-19 quarantine: Special focus in older people," Prog. Cardiovasc. Dis., vol. 63, no. 3, pp. 386-388, 2020, doi: 10.1016/j.pcad.2020.03.009.

[23] B. Glancy and R. S. Balaban, "Energy Metabolism Design of the Striated Muscle Cell," Physiol. Rev., Mar. 2021, doi: 10.1152/physrev.00040.2020.

[24] S. Chen et al., "The early impact of COVID-19 on mental health and community 
physical health services and their patients' mortality in Cambridgeshire and Peterborough, UK," J. Psychiatr. Res., vol. 131, pp. 244-254, 2020, doi: https://doi.org/10.1016/j.jpsychires.2020.09.020.

[25] S. Amatriain-Fernández, E. S. Murillo-Rodríguez, T. Gronwald, S. Machado, and H. Budde, "Benefits of physical activity and physical exercise in the time of pandemic.," Psychological Trauma: Theory, Research, Practice, and Policy, vol. 12, no. S1. Educational Publishing Foundation, Amatriain-Fernández, Sandra: Faculty of Sport Sciences and Physical Education, University of A Coruña, Avd. Ernesto Che Guevara 121, A Coruña, Spain, 15179, sandra.amatriain@udc.es, pp. S264-S266, 2020, doi: $10.1037 / \operatorname{tra} 0000643$.

[26] Z. Yan and H. R. Spaulding, "Extracellular superoxide dismutase, a molecular transducer of health benefits of exercise," Redox Biol., vol. 32, p. 101508, 2020, doi: https://doi.org/10.1016/j.redox.2020.101508.

[27] H. Kaur, T. Singh, Y. K. Arya, and S. Mittal, "Physical Fitness and Exercise During the COVID-19 Pandemic: A Qualitative Enquiry," Front. Psychol., vol. 11, p. 590172, Oct. 2020, doi: 10.3389/fpsyg.2020.590172.

[28] G. Maugeri et al., "The impact of physical activity on psychological health during Covid-19 pandemic in Italy," Heliyon, vol. 6, no. 6, p. e04315, 2020, doi: https://doi.org/10.1016/j.heliyon.2020.e04315.

[29] I. Muis, A. Agustang, and A. Adam, "Elderly poverty: Social demographic, work distribution, problem health \& social Protection," Asian J. Soc. Sci. Humanit., vol. 9, no. June, pp. 40-48, 2020, [Online]. Available: http://www.ajssh.leenaluna.co.jp/AJSSHPDFs/Vol.9(1)/AJSSH2020(9.1-05).pdf.

[30] World Healt Organization (WHO), "Physical Activity," News Room, 2020. https://www.who.int/news-room/fact-sheets/detail/physical-activity.

[31] G. Iolascon et al., "Personalized paths for physical activity: developing a personcentered quantitative function to determine a customized amount of exercise and enhancing individual commitment," BMC Sports Sci. Med. Rehabil., vol. 13, no. 1, p. 60, 2021, doi: 10.1186/s13102-021-00282-4.

[32] B. Nguyen, "GME: Gym in Medical Education-Maintaining Physical and Mental Well Being During the COVID-19 Pandemic," J. Wellness, vol. 3, no. 1, pp. 2-4, 2020, doi: 10.18297/jwellness/vol3/iss1/8.

[33] L. R. Amir et al., "Student perspective of classroom and distance learning during COVID-19 pandemic in the undergraduate dental study program Universitas Indonesia," BMC Med. Educ., vol. 20, no. 1, p. 392, 2020, doi: 10.1186/s12909-02002312-0.

[34] M. Churiyah and D. A. Sakdiyyah, "International Journal of Multicultural and Multireligious Understanding Indonesia Education Readiness Conducting Distance Learning in Covid-19 Pandemic Situation," Int. J. Multicult. Multireligious Underst., vol. 7, no. 6, pp. 491-507, 2020.

[35] R. R. Aliyyah et al., "The perceptions of primary school teachers of online learning during the COVID-19 pandemic period: A case study in Indonesia," J. Ethn. Cult. Stud., vol. 7, no. 2, pp. 90-109, 2020.

[36] S. Singh, D. Roy, K. Sinha, S. Parveen, G. Sharma, and G. Joshi, "Impact of COVID19 and lockdown on mental health of children and adolescents: A narrative review with recommendations," Psychiatry Res., vol. 293, p. 113429, 2020, doi: https://doi.org/10.1016/j.psychres.2020.113429.

[37] M. Indrawati, C. Prihadi, and A. Siantoro, "The Covid-19 Pandemic Impact on 
Children's Education in Disadvantaged and Rural Area Across Indonesia," Int. J. Educ., vol. 8, no. 4, pp. 19-33, 2020, doi: 10.5121/ije.2020.8403.

[38] I. P. Y. Purandina and I. M. A. Winaya, "Pendidikan Karakter di Lingkungan Keluarga Selama Pembelajaran Jarak Jauh pada Masa Pandemi COVID-19," Cetta J. Ilmu Pendidik., vol. 3, no. 2, pp. 270-290, Jun. 2020, doi: 10.37329/cetta.v3i2.454.

[39] D. Lase, S. E. Zaluchu, D. O. Daeli, and A. Ndraha, "Parents' Perceptions of Distance Learning during Covid-19 Pandemic in Rural Indonesia," 2020, doi: 10.35542/osf.io/hfza7.

[40] Akmaliyah, Y. Hudzaifah, N. Ulfah, and M. I. Pamungkas, "Child-friendly teaching approach for arabic language in nn indonesian islamic boarding school," Int. J. Lang. Educ., vol. 5, no. 1, pp. 501-514, 2021, doi: 10.26858/IJOLE.V5I1.15297.

[41] I. Hidayat, M. Hosnan, and Z. R. Halim, "Character Education Strengthen Discipline of StudentsBased on Extracurricular Pencak Silat State 2 Sempu Elementary School of Serang City," J. Primagraha, vol. 01, no. 01, pp. 84-99, 2020.

[42] J. R. Fraenkel and N. E. Wallen, Introduction to Qualitative Research: How to Design and Evaluate Research in Education, 7th ed. Boston, M.A.: McGraw-Hill, 2008.

[43] J. Gerring, Case Study Research: Principles and Practices. New York: Cambridge University Press, 2007.

[44] G. R. Asadullina, N. V. Korovkina, E. V. Sadretdinova, R. S. Badretdinovich, and N. G. Hajrullina, "Social Character: Issues of Methodology and Research Methods," Rev. Amaz. Investig., vol. 9, no. 26, pp. 545-553, 2020, doi: 10.34069/ai/2020.26.02.61.

[45] J. Heigham and R. Croker, Qualitative Research in Applied Linguistics: A Practical Introduction. New York: Palgrave Macmillan, 2009.

[46] U. Flick, "Triangulation in Data Collection," SAGE Res. Methods, 2018, doi: https://dx.doi.org/10.4135/9781526416070.n34.

[47] L. J. Moleong, Metodologi Penelitian Kualitatif. Bandung: PT. Remaja Rosdakarya Offset., 2013.

[48] H. Noble and R. Heale, "Triangulation in research, with examples," Evid. Based. Nurs., vol. 22, no. 3, pp. 67-68, 2019, doi: 10.1136/ebnurs-2019-103145.

[49] K. Roulston, "Triangulation in qualitative research," QualPage, 2018. https://qualpage.com/2018/01/18/triangulation-in-qualitative-research/.

[50] M. B. Miles and A. M. Huberman, Qualitative Data Analysis: An Expanded Sourcebook, 2nd ed. California: SAGE Publications Inc., 1994.

[51] S. M. Renz, J. M. Carrington, and T. A. Badger, "Two Strategies for Qualitative Content Analysis: An Intramethod Approach to Triangulation," SAGE Journals, vol. 28, no. 5, pp. 824-831, 2019, doi: https://doi.org/10.1177/1049732317753586.

[52] R. of I. Ministry of Education and Culture, PERMENDIKBUD Nomor 62 Tahun 2014, vol. 53, no. 9. 2014, pp. 1689-1699.

[53] D. R. Rizaldi and Z. Fatimah, "How the Distance Learning can be a Solution during the Covid-19 Pandemic," Int. J. Asian Educ., vol. 1, no. 3, pp. 117-124, 2020, doi: 10.46966/ijae.v1i3.42.

[54] N. W. Rahayu and S. Haningsih, "Digital parenting competence of mother as informal educator is not inline with internet access," Int. J. Child-Computer Interact., vol. 29, p. 100291, 2021, doi: https://doi.org/10.1016/j.ijcci.2021.100291.

[55] L. C. Bates et al., "COVID-19 Impact on Behaviors across the 24-Hour Day in Children and Adolescents: Physical Activity, Sedentary Behavior, and Sleep," Children , vol. 7, no. 9. 2020, doi: 10.3390/children7090138.

[56] A. Pombo, C. Luz, L. P. Rodrigues, C. Ferreira, and R. Cordovil, "Correlates of 
children's physical activity during the COVID-19 confinement in Portugal," Public Health, vol. 189, pp. 14-19, 2020, doi: https://doi.org/10.1016/j.puhe.2020.09.009.

[57] B. Kartowagiran, S. Hamdi, E. Istiyono, A. Fauzi, M. Ayub, and S. S. Dewanti, "Integrating the 21st Century Character Values for Elementary School Students," Elem. Educ. Online, vol. 20, no. 2, pp. 33-43, 2021, doi: 10.17051/ilkonline.2021.02.07. 